\title{
Spectrometric and Electrochemical Investigation of Vanadium(V) and Vanadium(IV) Tartrate Complexes in Solution
}

\author{
Ahmad R. Khan, ${ }^{a}$ Debbie C. Crans, ${ }^{a}$ Rasa Pauliukaite ${ }^{\#, b}$ and Eugenijus Norkus, ${ }^{*, b}$ \\ ${ }^{a}$ Department of Chemistry, Colorado State University, Fort Collins, CO 80523-1872, USA \\ ${ }^{b}$ Department of Catalysis, Institute of Chemistry, A. Goštauto 9, LT-01108 Vilnius, Lithuania
}

Os complexos de vanádio(IV) e (V) com tartarato formados em solução e as suas possíveis interconversões foram estudados utilizando-se técnicas espectroscópicas e eletroquímicas. A investigação foi feita através de espectroscopia de NMR de ${ }^{51} \mathrm{~V}$ combinada com ${ }^{1} \mathrm{H}$, de NMR de ${ }^{13} \mathrm{C}$ e espectroscopia de EPR. Como técnicas electroquímicas utilizaram-se a polagrografia e a voltametria cíclica. Verificou-se que complexo que se forma em maior extensão, em quase todo o intervalo de $\mathrm{pH}$, é o de vanádio(V)-tartarato na proporção 1:1. O complexo 1:2 apresentou menor contribuição. Estes complexos foram formados a partir do complexo de vanádio(IV)-tartarato $2: 2$. A caracterização electroquímica de $\mathrm{V}(\mathrm{V})$ em solução na presença de tartarato por polarografia e por voltametria cíclica demonstrou a formação de complexos. Foram determinados os coeficientes de difusão dos íons livres de vanádio e dos complexos de vanádio-tartarato. Os valores dos coeficientes de difusão foram de $3 \times 10^{-6} \mathrm{~cm}^{2} \mathrm{~s}^{-1}$ a $17 \times 10^{-6} \mathrm{~cm}^{2} \mathrm{~s}^{-1}$, dependendo do $\mathrm{pH}$.

Spectroscopic and electrochemical studies were carried out to characterize the vanadium(IV) and (V) complexes that form in solution and their interconversions. ${ }^{51} \mathrm{~V}$ NMR spectroscopy coupled with ${ }^{1} \mathrm{H} \mathrm{NMR},{ }^{13} \mathrm{C}$ NMR and EPR spectroscopy were used to characterize the vanadium(V)-tartrate complexes that form in the vanadium-tartrate system. The major complex that forms over most of the $\mathrm{pH}$ range is a 1:1 complex. In addition a minor 1:2 complex forms. The 1:2 complex formed from enantiomerically pure tartaric acid was less stable than complex formed from racemic tartaric acid. These complexes are different than the $2: 2$ complex that is the major contributor in the vanadium(IV)-tartrate system. The polarographic and cyclic voltammetic investigations of the electrochemical behavior of $\mathrm{V}(\mathrm{V})$ in the presence of tartrate demonstrated a complex formation. The diffusion coefficient values of free vanadium ions and vanadium-tartrate complexes were determined. The minimum average values for the diffusion coefficient for the vanadium(IV)-tartrate 2:2 complexes were determined to range from $3 \times 10^{-6} \mathrm{~cm}^{2} \mathrm{~s}^{-1}$ to $17 \times 10^{-6} \mathrm{~cm}^{2} \mathrm{~s}^{-1}$ depending on $\mathrm{pH}$.

Keywords: vanadium(V), vanadium(IV), tartrate complexes, NMR and EPR spectroscopy, electrochemistry

\section{Introduction}

Characterization of complexes that could potentially form and exist under biological conditions is of current interest given the anti-diabetic properties of vanadium compounds. ${ }^{1}$ Furthermore, the role of vanadium compounds as cofactor in haloperoxidases, ${ }^{2}$ nitrogenases ${ }^{3}$ and the analog between vanadate and phosphate ${ }^{4}$ has stimulated a surge in the interest in aqueous vanadium

*e-mail: Norkus@ktl.mii.lt

\# Current Address: Departamento de Química, Universidade de Coimbra, 3004-535 Coimbra, Portugal chemistry. Tartaric acid is produced by microorganisms in large quantities and is formed in the human metabolism In general, alpha-hydroxy carboxylates are strong metal chelators, and in the case of tartrate the three different stereoisomers $(\mathrm{D}(-)$-tartrate, $\mathrm{L}(+)$-tartrate and $\mathrm{DL}(\bar{\mp})$ tartrate), further allow for geometrically intriguing coordination complexes.

The variety of oxidation states of the metal in vanadium complexes implies that the redox reactions under physiological conditions are important to the action of these complexes. ${ }^{1}$ The redox processes are more likely to take place in the presence of an organic ligand such as tartrate. Vanadium-tartrate systems 
reported in the literature include a crystallographic characterization and solution study. ${ }^{5-8}$ The chemistry of vanadium(IV)-tartrate complexes have been studied. ${ }^{8}$ The structurally characterized 2:2 vanadium(IV) tartaric acid complex contains two tartaric acid ligands (of DL $(\mp)$ stereochemistry) coordinating to each vanadium atom in a bidentate manner. ${ }^{7}$ The $\mathrm{V}(\mathrm{IV})$ complexation with L(+)- and DL $(\bar{\mp})$-tartaric acid as monitored by spectrophotometry and EPR confirmed that 2:2 anionic complexes exist in solution. At neutral $\mathrm{pH}$, spectral differences were observed between the $\mathrm{L}(+)$-complex and the DL( $\bar{\mp}$-complex; the last one was found to be more stable. ${ }^{6}$ Recent comprehensive potentiometric and EPR spectroscopic investigations of the vanadium(IV) complexes with tartrate isomers confirmed the formation of the dinuclear complex from $\mathrm{V}(\mathrm{IV})$ and the $\mathrm{D}(-)-, \mathrm{L}(+)$ - and $\mathrm{DL}(\bar{\mp})$-tartrate systems. In contrast, a cyclic trinuclear species formed from V(IV) and mesotartrate. ${ }^{9}$ One spectrophotometric study was carried out from vanadate and tartaric acid at $\mathrm{pH} 2.8-3.4$, and a weak $2: 1$ complex $(\log \beta=3.1)$ was observed. ${ }^{5}$

The current study was carried out to provide benchmark information on the properties of physiological relevant vanadium(IV) and (V) complexes. Specifically, we selected a system in which both oxidation states could be characterized and the conversion between oxidation states could be investigated. Multinuclear NMR and EPR spectroscopy, polarography and cyclic voltammetry were used to characterize the vanadium-tartrate system, beginning with the detailed characterization of the vanadium(V)-tartrate complexes.

\section{Experimental}

\section{Materials}

All chemicals were of the highest purity grade and were used as provided by Sigma-Aldrich chemical company. L(+)-, D(-)- and DL( $(\overline{+})$-tartaric acid were all used for these studies even though most experiments were performed with $\mathrm{L}(+)$-tartaric acid.

\section{Polarography}

The polarographic curves were recorded by a PU-1 polarograph (Belarus) using a dropping mercury electrode in a three-electrode cell, equipped with a thermostat. ${ }^{10}$ The reported experiments were carried out at $20 \pm 0.1{ }^{\circ} \mathrm{C}$ (selected measurements were also carried out at 25 and $30{ }^{\circ} \mathrm{C}$ ). The potential scanning rate was $100 \mathrm{mV} \mathrm{min}^{-1}$. The capillary characteristics at $20^{\circ} \mathrm{C}$ were $m=2.95 \mathrm{mg} \mathrm{s}^{-1}$ and $t=3.73 \mathrm{~s}$. The reference electrode was an $\mathrm{Ag} / \mathrm{AgCl}$ electrode filled with saturated $\mathrm{KCl}$. All potential values are referred to the standard hydrogen electrode (SHE).

The polarograms were recorded in $1.0 \mathrm{mmol} \mathrm{L}^{-1}$ sodium metavanadate $\left(\mathrm{NaVO}_{3} \cdot 2 \mathrm{H}_{2} \mathrm{O}\right)$ solutions and tartaric acid at a ratio $1: 1$ to $1: 10$ metal to ligand. Supporting electrolyte was $600 \mathrm{mmol} \mathrm{L}^{-1}$ of $\mathrm{NaCl}$. Oxygen was removed from the solutions by purging Ar through the solution. The Ar flow was maintained on top of the solution during the course of experiment. Applied potential was swept from +0.1 to $-1.6 \mathrm{~V} v$ s. SHE.

\section{Cyclic voltammetry}

The cyclic voltammograms ${ }^{11}$ were recorded by a PI50 potentiostat (Russia) using three-electrode thermostated electrochemical cell. The working electrode was a smooth Pt foil of $1 \mathrm{~cm}^{2}$, the auxiliary electrode, a Pt foil of $3 \mathrm{~cm}^{2}$, and the reference electrode was an $\mathrm{Ag} / \mathrm{AgCl}$ electrode filled with saturated $\mathrm{KCl}$. Applied potential was cycled from -0.75 to $+1.1 \mathrm{~V}$ at potential scan rate $50 \mathrm{mV} \mathrm{s}^{-1}$ for 3 times. Supporting electrolyte was $600 \mathrm{mmol} \mathrm{L}^{-1} \mathrm{NaCl}$ solution. Sodium metavanadate concentration was 10 mmol L $\mathrm{L}^{-1}$ and its concentration ratio with tartaric acid varied from 1:1 to 1:3. $\mathrm{pH}$ was adjusted either with $\mathrm{HCl}$ or with $\mathrm{NaOH}$ solutions. ${ }^{12}$ Oxygen was removed from the solutions by purging Ar through the solution. The Ar flow was maintained on top of the solution during the course of experiment. The experiments were carried out at $20 \pm 0.1{ }^{\circ} \mathrm{C}$.

\section{NMR and EPR spectroscopy}

The NMR spectra were recorded on a Varian Inova300 spectrometer (USA) at $78.9 \mathrm{MHz}(7.0 \mathrm{~T})$ for ${ }^{51} \mathrm{~V}$, at $75.46 \mathrm{MHz}{ }^{13} \mathrm{C}$ and at $300 \mathrm{MHz}$ for ${ }^{1} \mathrm{H}$. The ${ }^{51} \mathrm{~V}$ is a quadrupolar nucleus and with high natural abundance and a frequency near that of ${ }^{13} \mathrm{C}$. The parameters used for recording the ${ }^{51} \mathrm{~V}$ NMR spectra were as follows; a sweep width of $33000 \mathrm{~Hz}$, a pulse width of $90^{\circ}$ and an acquisition time of $0.050 \mathrm{sec}^{13}$ The chemical shifts were recorded against an external standard of $\mathrm{VOCl}_{3}$ $(0 \mathrm{ppm}) .{ }^{13}$ The spectra were processed using no linebroadening or baseline correction. Spectra were integrated using the Varian software, and the concentrations calculated from the mole fraction of each signal. The ${ }^{1} \mathrm{H}$ and ${ }^{13} \mathrm{C}$ NMR chemical shifts were referenced against an external sample of 3-(trimethylsilyl)-1-propanesulfonic acid sodium salt (DSS) at ambient temperature. ${ }^{13}$ The EPR spectra were recorded on a Bruker EMX spectrometer (USA). The 
X-band EPR spectra were recorded at ambient temperature in $1 \mathrm{~mm}$ quartz capillary tubes that were placed in $5 \mathrm{~mm}$ quartz EPR tubes. The spectra were recorded between 9.750 and $9.900 \mathrm{GHz}$ (X-band) and at $40 \mathrm{~mW}$ microwave power and the quantitative parameters described previously: ${ }^{14}$ concentration of vanadium(IV) compounds were varied from 10 to 50 mmol L-1 and were recorded in the aqueous sodium chloride solutions. Quantification of EPR signals was performed by double integration of the first-derivate spectra to obtain the area under the absorption curve.

\section{Sample preparation for ${ }^{5 l} \mathrm{~V} N M R(E P R)$ spectroscopic studies}

Sample solutions were prepared from the stock solutions and were analyzed by ${ }^{1} \mathrm{H},{ }^{51} \mathrm{~V}$ and ${ }^{13} \mathrm{C}$ NMR spectroscopy. Concentrations of the stock solutions were 50 and $1000 \mathrm{mmol} \mathrm{L}^{-1}$ sodium metavanadate, 100, 500 and $2000 \mathrm{mmol} \mathrm{L}^{-1}$ tartaric acid and $2.00 \mathrm{~mol} \mathrm{~L}^{-1} \mathrm{NaCl}$. The $\mathrm{pH}$ of the tartaric acid solution was adjusted to the desired $\mathrm{pH}$ (2.45 and 6.50). The stock solutions were prepared either in $\mathrm{H}_{2} \mathrm{O}$ or $\mathrm{D}_{2} \mathrm{O}$ depending on the mode of analyses to be carried out.

The solutions prepared in the neutral and alkaline $\mathrm{pH}$ range were prepared by the addition of vanadate, tartaric acid followed by $\mathrm{NaCl}$. In the near neutral $\mathrm{pH}$ range studies, the tartaric acid solution was adjusted because no acid can be added to the vanadate-tartaric acid solution due to formation of decavanadate at acidic $\mathrm{pH}$. The samples at acidic $\mathrm{pH}$ values were prepared similarly. A wide range of concentration ranges were investigated; various combinations from 0.40 to 500 mmol L-1 vanadate and from 0.40 to $800 \mathrm{mmol} \mathrm{L}^{-1}$ tartaric acid. The $\mathrm{NaCl}$ concentration was maintained at 600 mmol L-1 to keep ionic strength constant, except for the structural studies using ${ }^{1} \mathrm{H}$ and ${ }^{13} \mathrm{C}$ NMR spectroscopy where no salt was added.

\section{Interpretation of NMR spectra}

The concentrations of vanadium species were calculated from the mole fractions of each species signal and the known overall concentration of vanadium(V). This method assumes that no redox processes have taken place and thus most reliable for freshly prepared solutions in a system such as the vanadate-tatrate system. The vanadate oligomers observed in the ${ }^{51} \mathrm{~V}$ NMR spectra include monomer $\left(\mathrm{V}_{1}\right.$; defined as the sum of $\mathrm{H}_{2} \mathrm{VO}_{4}^{-}$or $\left.\mathrm{HVO}_{4}{ }^{2-}\right)$, dimer $\left(\mathrm{V}_{2}\right)$ and tetramer $\left(\mathrm{V}_{4}\right)$; these species are related as shown in equations (1) and (3). ${ }^{13}$ The concentration of
$\mathrm{VO}_{2}{ }^{+}$was obtained directly from the integration of the spectra at acidic $\mathrm{pH}$. Since decavanadate gives three signals (-416, -499 and $-515 \mathrm{ppm}$ ), the two signals can be used to calculate the component of the third signal that overlap with the V-tratrate complex. Thus, the difference is assigned to the $\mathrm{V}$-tartrate complex. The formation constants and stoichiometries of the complexes were investigated both at low and high $\mathrm{pH}$ ranges using equations (4)-(7). By using $\mathrm{H}_{2} \mathrm{VO}_{4}^{-}$, $\operatorname{tar}^{2-}$ and $\mathrm{H}^{+}$to carry out a study in which $\mathrm{H}^{+}$is also varied, the charge of the complex can also be determined.

$$
\begin{aligned}
2 \mathrm{~V}_{1} & \rightarrow \mathrm{V}_{2} \\
4 \mathrm{~V}_{1} & \rightarrow \mathrm{V}_{4} \\
2 \mathrm{~V}_{2} & \rightarrow \mathrm{V}_{4} \\
\mathrm{~V}_{1}+\operatorname{tar} & \rightarrow \mathrm{Vtar} \\
\mathrm{V}_{1}+2 \operatorname{tar} & \rightarrow \mathrm{Vtar}_{2} \\
2 \mathrm{~V}_{1}+\operatorname{tar} & \rightarrow \mathrm{V}_{2} \operatorname{tar} \\
2 \mathrm{~V}_{1}+2 \operatorname{tar} & \rightarrow \mathrm{V}_{2} \operatorname{tar}_{2}
\end{aligned}
$$

Structural studies were conducted using ${ }^{1} \mathrm{H}$ and ${ }^{13} \mathrm{C}$ NMR spectroscopy at acidic $\mathrm{pH}$ using the samples described above at varies concentrations of ligand and vanadate. Selected ${ }^{1} \mathrm{H}$ and ${ }^{13} \mathrm{C}$ NMR spectra were investigated at both ambient and low temperature; however due to sample instability and multiple complexes the quality of the ${ }^{13} \mathrm{C}$ NMR spectra were limited. Reducing the temperature slow down some of the exchange processes, and signals sharpen somewhat; since the samples are studied in aqueous solution these studies were only conducted from $\sim-5$ to $25{ }^{\circ} \mathrm{C}$. Accompanying ${ }^{51} \mathrm{~V}$ NMR spectra were recorded to verify the composition of the samples.

\section{Calculation of diffusion coefficients}

The values of the diffusion coefficient $(D)$ were calculated using the Ilkovic equation, ${ }^{15}$

$D^{1 / 2}=\frac{\bar{i}_{\text {dif }}}{607 \mathrm{ncm}^{2 / 3} t^{1 / 6}}$,

where is the limiting diffusion current (A), $n$ is a number of electrons involved in the electrode reaction, $c$ is the concentration $\left(\mathrm{mmol} \mathrm{L}^{-1}\right), m$ is the flow rate of $\mathrm{Hg}\left(\mathrm{mg} \mathrm{s}^{-1}\right)$, and $t$ is the time of the formation of the drop (s). 


\section{Results and Discussion}

\section{Spectroscopic investigations of the vanadium(V)-tartrate} system

NMR studies at various $p H$. In a series of spectra of 10 vanadate and $100 \mathrm{mmol} \mathrm{L}^{-1} \mathrm{~L}$-tartaric acid recorded from pH 6.5 to $\mathrm{pH} 10$, two new complexes were observed at -495.7 and -516.1 ppm (Figure 1). A minor signal observed at -529 ppm at pH 6.7 may be a third complex; the possibility that this complex was the oxovanadate complex reported previously was considered and not ruled out. ${ }^{16}$ The complex at -495.7 ppm shift was found to shift at higher $\mathrm{pH}$ (Figure 2). Redox chemistry was found to take place in these samples, as evidenced by the appearance of decomposition products (NMR spectroscopy) as well as changes in solution color (visible spectroscopy). The rate of redox reaction was larger in solutions with high concentration of vanadate and tartrate at low $\mathrm{pH}$. In all cases, the results described here are from freshly prepared solutions.

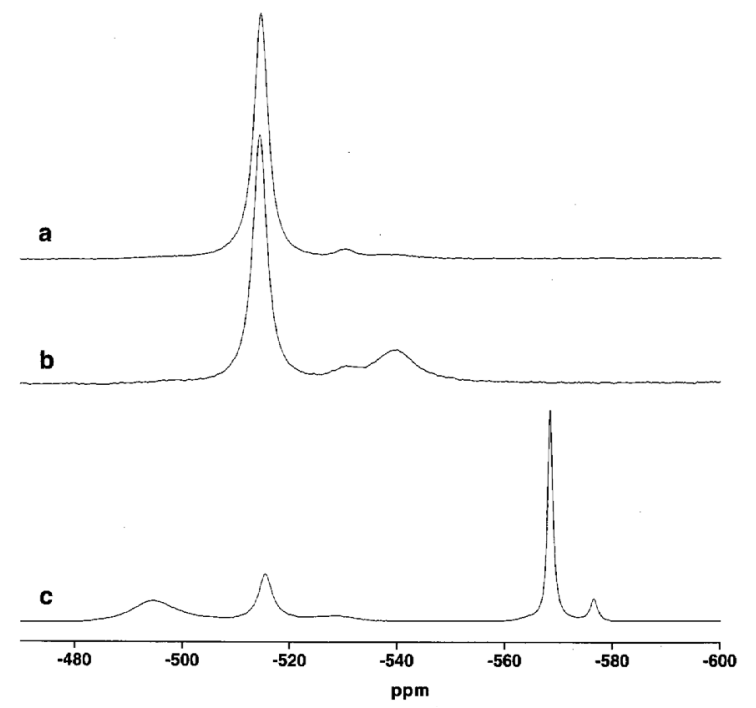

Figure 1. ${ }^{51} \mathrm{~V}$ NMR spectra of solutions of vanadate and L(+)-tartratic acid. a) $10 \mathrm{mmol} \mathrm{L}^{-1}$ vanadate and $10 \mathrm{mmol} \mathrm{L}^{-1} \mathrm{~L}(+)$-tartratic acid in $600 \mathrm{mmol}$ $\mathrm{L}^{-1} \mathrm{NaCl}$ at $\mathrm{pH} 2.5$. b) $10 \mathrm{mmol} \mathrm{L}^{-1}$ vanadate and $35 \mathrm{mmol} \mathrm{L}^{-1}$ of $\mathrm{L}(+)$-tartratic acid in $600 \mathrm{mmol} \mathrm{L}^{-1} \mathrm{NaCl}$ at $\mathrm{pH}$ 2.5. c) $10 \mathrm{mmol} \mathrm{L}^{-1}$ vanadate and 100 mmol L-1 $\mathrm{L}(+)$-tartratic acid in $600 \mathrm{mmol} \mathrm{L}^{-1} \mathrm{NaCl}$ at $\mathrm{pH} 6.7$.

The initial studies were expanded to include $\mathrm{pH}$ range 2 to 9 by recording NMR spectra of solutions containing vanadate and tartaric acid $\left(10 \mathrm{mmmol} \mathrm{L}^{-1} /\right.$ $10 \mathrm{mmol} \mathrm{L}^{-1}, 10 \mathrm{mmol} \mathrm{L}^{-1} / 30 \mathrm{mmol} \mathrm{L}^{-1}$ and $15 \mathrm{mmol} \mathrm{L}^{-1}$ / $200 \mathrm{mmol} \mathrm{L}^{-1}$ ). Complexes were observed in this entire $\mathrm{pH}$ range, and are shown in Figure 2. One complex is observed at alkaline $\mathrm{pH}(-495 \mathrm{ppm})$ and a second complex is observed at $-515 \mathrm{ppm}$ in addition to the complex at $-495 \mathrm{ppm}$ at neutral pH. From pH 3.5 to
4.5, four complexes are observed at $-574 \mathrm{ppm},-539$ ppm, -515 ppm and -485 ppm, however, only the three complexes at $-570 \mathrm{ppm},-539 \mathrm{ppm}$ and $-515 \mathrm{ppm}$ are observed below pH 3.5. As it is shown in Figure 2, the chemical shifts of two of the four complexes (-539 ppm and $-515 \mathrm{ppm}$ ) are $\mathrm{pH}$ independent. However, the signal at $-574 \mathrm{ppm}$ at $\mathrm{pH} 4$ decreases to $-569 \mathrm{ppm}$ at $\mathrm{pH} 2.5$. The signal at $-495 \mathrm{ppm}$ decreases as the $\mathrm{pH}$ continues to decrease from $\mathrm{pH}$ 6. At $\mathrm{pH}$ of 3.7 , the chemical shift is approximately $-478 \mathrm{ppm}$ and no signal is observed below this $\mathrm{pH}$.

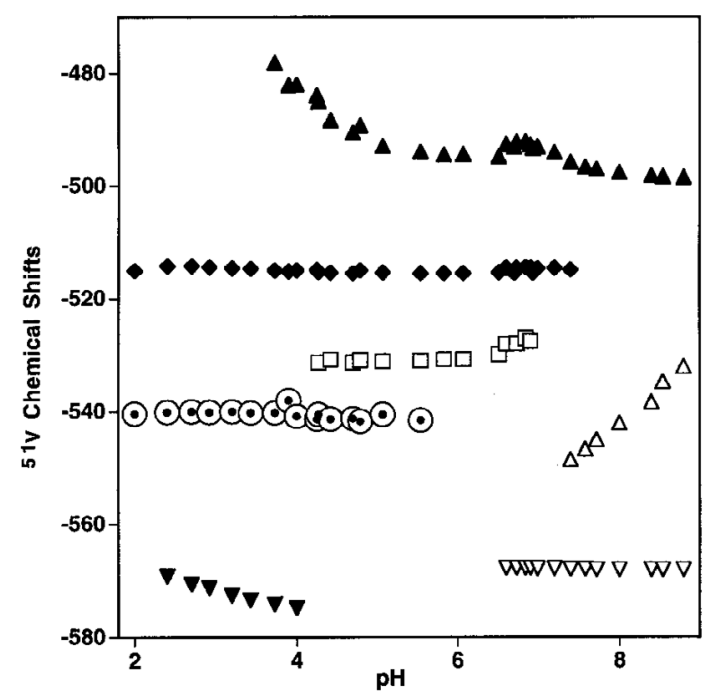

Figure 2. Chemical shifts for vanadium(V) species shown as a function of $\mathrm{pH}$. The figure shows data obtained at $15 \mathrm{mmol} \mathrm{L}^{-1}$ vanadate and 200 mmol L ${ }^{-1} \mathrm{~L}(+)$-tartaric acid from $\mathrm{pH} 2$ to 9 , and the species are indicated as follows: $\mathrm{H}_{2} \mathrm{VO}_{4}^{-}\left(\triangle\right.$, open triangle tip up), $\mathrm{V}_{4} \mathrm{O}_{12}{ }^{4-}(\nabla$, open triangle tip down), $\mathrm{VO}_{2}{ }^{+}\left(\mathrm{O}\right.$, open circle), minor species (or oxovanadate ${ }^{16}$ ) ( $\square$, open square), complexes between vanadate and L-tartaric acid at $-570 \mathrm{ppm}(\boldsymbol{\nabla}$, solid triangle tip down) $-539 \mathrm{ppm}(\boldsymbol{\bullet}$, solid circle), -515 $\operatorname{ppm}(\diamond$, solid diamond) and $-495 \mathrm{ppm}(\boldsymbol{\Lambda}$, solid triangle tip up).

Stoichiometry studies at neutral $\mathrm{pH}$. The stoichiometry of the complexes at $-515 \mathrm{ppm}$ and at $-495 \mathrm{ppm}$ was investigated using 1 to $10 \mathrm{mmol} \mathrm{L}^{-1}$ vanadate, from 10 to $50 \mathrm{mmol} \mathrm{L}^{-1}$ tartaric acid, and at $\mathrm{pH}$ values from 6.5 to 7.05 and $600 \mathrm{mmol} \mathrm{L}^{-1} \mathrm{NaCl}$. The data were analyzed using equations (4) to (7). Since a linear relationship is obtained when plotting complex as a function of $\left[\mathrm{V}_{1}\right]$ vs. [tartrate] it has been concluded that the complex at -515 ppm is a 1:1 complex. The relationship furthermore shows that 2 protons are used upon complex formation. By corresponding analysis, the signal at $-495 \mathrm{ppm}$ is also found to be a 1:1 complex consuming no more than one proton upon complex formation.

Stoichiometry studies at acidic $p H$. A series of spectra of $10 \mathrm{mmol} \mathrm{L}^{-1}$ vanadate and 10, 20 and $30 \mathrm{mmol} \mathrm{L}^{-1}$ tartaric acid with $600 \mathrm{mmol} \mathrm{L}^{-1} \mathrm{NaCl}$ were recorded 
from $\mathrm{pH} 2.30$ to 2.50 . Two new complexes were observed in these spectra in the presence of the major complex at $-515 \mathrm{ppm}$ and a minor complex at $-539 \mathrm{ppm}$ (Figure 1). The major species overlap one of the signals for decavanadate and the minor species overlap the signal for $\mathrm{VO}_{2}{ }^{+}$at these low $\mathrm{pH}$ values. The signal at $-515 \mathrm{ppm}$ is even observed when little decavanadate is present ( 0 to $2 \%$ ). The $-539 \mathrm{ppm}$ signal increases by the addition of increasing tartaric acid concentrations. In the neutral $\mathrm{pH}$ range, signals were observed for both the oxovanadate complex (at $-529 \mathrm{ppm}$ ) and decavanadate (at $-416,-499$ and $-515 \mathrm{ppm}$ ). At high tartaric acid concentrations in solutions from $\mathrm{pH} 2.5$ to $\mathrm{pH} 4.5$, a new species was observed at about $-570 \mathrm{ppm}$.

The stoichiometry of the complexes at $-515 \mathrm{ppm}$ and at $-539 \mathrm{ppm}$ was investigated using several concentration ranges of vanadate and tartaric acid. The concentration range from 2 to $10 \mathrm{mmol} \mathrm{L}^{-1}$ vanadate was combined with 2 to $10 \mathrm{mmol} \mathrm{L}^{-1}$ tartaric acid, at $\mathrm{pH} \sim 2.5$ with 600 mmol L-1 $\mathrm{NaCl}$. In this series, the complex at $-539 \mathrm{ppm}$ (overlapping the $\mathrm{VO}_{2}^{+}$signal) was not observed. Any contribution of decavanadate to $-515 \mathrm{ppm}$ signal was taken into account by measuring the decavanadate signal at $-499 \mathrm{ppm}$ and subtracting this from the total observed signal at $-515 \mathrm{ppm}$. The concentration range used for stoichiometric studies was $10 \mathrm{mmol} \mathrm{L}^{-1}$ vanadate and 15 to $35 \mathrm{mmol} \mathrm{L}^{-1}$ tartaric acid at $\mathrm{pH} \sim 2.5$ with $600 \mathrm{mmol}$ $\mathrm{L}^{-1} \mathrm{NaCl}$. Since the chemical shift of the complex was superimposed on the free $\mathrm{VO}_{2}^{+}$, the concentration of the $\mathrm{VO}_{2}{ }^{+}$was assumed to be the same as the oxovanadate complex at $-529 \mathrm{ppm}$. At low concentrations of tartaric acid in the sample solutions, the concentration of the oxovanadate species was similar to that of the free $\mathrm{VO}_{2}{ }^{+}$ species. Results obtained from these series of spectra are interpreted below.

Spectra from solutions containing 1:1 metal to ligand ratio in the concentration range from 2 to 3.5 mmol L ${ }^{-1}$ vanadate and 0.5 to $3.0 \mathrm{mmol} \mathrm{L}^{-1}$ tartaric acid showed that the signal at $-515 \mathrm{ppm}$ is likely to be a $1: 1$ (metal:ligand) species. This conclusion is based on the linear relationship between the concentration of -515 ppm species and that of $\left[\mathrm{VO}_{2}^{+}\right] v s$. $\left[\operatorname{tar}^{2-}\right]$. Plotting the concentration of complex (from the $-539 \mathrm{ppm}$ peak) from data of a series of concentrations of $10 \mathrm{mmol} \mathrm{L}^{-1}$ vanadate and varying concentration of tartaric acid above $10 \mathrm{mmol} \mathrm{L}^{-1}$, gave a linear relationship both as a function of $\left[\mathrm{VO}_{2}^{+}\right]$vs. $\left[\mathrm{H}_{2} \mathrm{tar}\right]^{2}$ and $\left[\mathrm{VO}_{2}^{+}\right]^{2}$ vs. $\left[\mathrm{H}_{2} \mathrm{tar}\right]^{2}$, respectively. Unfortunately, redox chemistry (see below) prevented from investigating solutions with increasing concentrations of vanadate, and prevented clear distinction between the 1:2 and 2:2 complexes by such plots. Solutions of 1:1 vanadate and tartaric acid below $10 \mathrm{mmol} \mathrm{L}^{-1}$ vanadate did not form a complex at $-539 \mathrm{ppm}$ as the stability of the 1:1 complex precluded formation of other complexes (Also, no decavanadate are observed in these solutions). However, the dramatic increase of the complex at $-539 \mathrm{ppm}$ in solutions containing 10 -fold excess tartaric acid is consistent with this species being a 1:2 complex.

Solution structure. Solution structure can be investigated by measuring the change of signals in free ligand to complex (coordination induced shift abbreviated CIS). Using ${ }^{13} \mathrm{C}$ NMR spectroscopy to determine the solution structure of the major 1:1 complex present at acidic $\mathrm{pH}$. Two peaks at $72 \mathrm{ppm}$ and $175 \mathrm{ppm}$ were observed for tartaric acid (ligand) at $\mathrm{pH} 2.5$ at ambient and at low temperature $\left(5^{\circ} \mathrm{C}\right)$. In solutions containing one ${ }^{51} \mathrm{~V}$ NMR signal at $-515 \mathrm{ppm}$ with $600 \mathrm{mmol} \mathrm{L}^{-1}$ of vanadate and tartaric acid at $\mathrm{pH} 2.5$ no ${ }^{13} \mathrm{C}$ NMR signals were observed at ambient temperature but two peaks at $89 \mathrm{ppm}$ and 184 ppm were observed at $5{ }^{\circ} \mathrm{C}$. This corresponds to a CIS of 17 and $9 \mathrm{ppm}$. These signals were also observed at ambient temperature when solutions of $500 \mathrm{mmol} \mathrm{L}^{-1}$ vanadate and $500 \mathrm{mmol} \mathrm{L}^{-1}$ tartaric acid were prepared at $\mathrm{pH} 3.9$ (by ${ }^{51} \mathrm{~V}$ NMR the complex at $-515 \mathrm{ppm}$ was the major species). The size of the carboxylate CIS shift (9 ppm) indicates that both the carboxylates are chelated to the vanadium. In addition, the large $20 \mathrm{ppm}$ CIS of the carbon atoms adjacent to the hydroxyl groups suggests that these groups are deprotonated and chelated as alkoxide ligands to the vanadium. Studies by ${ }^{1} \mathrm{H}$ NMR spectroscopy supported these conclusions, as the complex signal was observed at $5.2 \mathrm{ppm}$ and the free ligand at $4.7 \mathrm{ppm}$, the protons adjacent to the hydroxyl group support coordination of the hydroxyl group to the vanadium. The ${ }^{1} \mathrm{H}$ NMR spectra were more complex than the ${ }^{13} \mathrm{C}$ NMR spectra in that more than the signals described above were present. Presumably these signals are due to decomposition products and the 1:2 complex. A structural proposal consistent with these data would have all four oxygen atoms coordinated to the vanadium atoms, however, the stoichiometry requires that two of the oxygen atoms are protonated. Three structural possibilities are given below (Scheme 1).
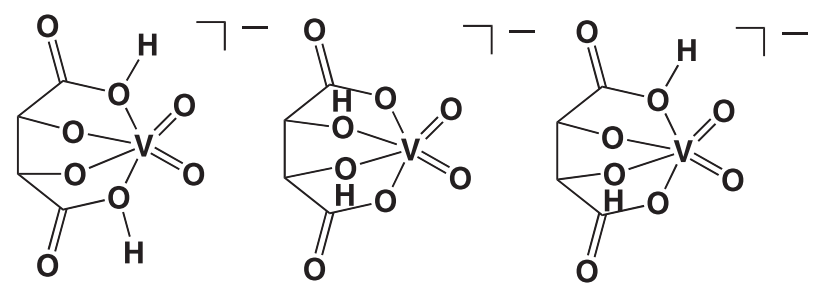

Scheme 1. 
Attempts to characterize the solution structure of the 1:2 (metal: ligand) complex were unsuccessful (500 mmol L-1 vanadate and $800 \mathrm{mmol} \mathrm{L}^{-1}$ tartaric acid) at $\mathrm{pH}$ 2.50 and at $\mathrm{pH} 4.00$ at both ambient and low temperature $\left(5{ }^{\circ} \mathrm{C}\right)$. Low concentration of each isomer and the rapid redox processes that take place in these solutions presumably is what limit these observations even in freshly prepared solutions.

Do vanadium(IV)-tartrate complexes form in solution of vanadate and tartrate?

The solution color changes indicate that redox chemistry of the vanadate-tartrate system is taking place in the acidic $\mathrm{pH}$ range. The rate of color change increased with the increasing concentration of tartaric acid. Three distinct color changes from orange were observed of sample solutions in the presence of 600 mmol L-1 $\mathrm{NaCl}$ at $\mathrm{pH} \sim 2.5$ : to green within $24 \mathrm{~h}$ (from 2.5 to $7.0 \mathrm{mmol} \mathrm{L}^{-1}$ vanadate and tartaric acid), to yellow within $12 \mathrm{~h}$ (from 7.5 to $10 \mathrm{mmol} \mathrm{L}^{-1}$ vanadate and tartaric acid) and to blue within $4 \mathrm{~h}$ (at $10 \mathrm{mmol} \mathrm{L}^{-1}$ vanadate and from $15 \mathrm{mmol} \mathrm{L}^{-1}$ to $35 \mathrm{mmol} \mathrm{L}^{-1}$ tartaric acid). The detailed characterization of the speciation in the vanadium(IV)-tartrate system show that both $1: 1$ and 2:2 complexes form. EPR spectroscopic studies were therefore conducted to confirm formation of the previously reported species. ${ }^{9}$

In freshly prepared sample solutions containing 600 mmol L ${ }^{-1} \mathrm{NaCl}\left(7.0 \mathrm{mmol} \mathrm{L}^{-1}\right.$ vanadate and $6.5 \mathrm{mmol}$ $\mathrm{L}^{-1}$ tartrate acid/10 $\mathrm{mmol} \mathrm{L}^{-1}$ vanadate and $35 \mathrm{mmol}$ $\mathrm{L}^{-1}$ tartrate acid), the concentration of $\mathrm{V}(\mathrm{IV})$ species increases with increasing tartrate concentration (Figure 3 ). Initially, about 3-10\% of total vanadate were immediately observed in the samples. Within $48 \mathrm{~h}, 90$ to $95 \%$ of $\mathrm{V}(\mathrm{IV})$ species form. In a $6.5 \mathrm{mmol} \mathrm{L}^{-1}$ / $7.0 \mathrm{mmol} \mathrm{L}^{-1}$ sample, two species are observed; the spectra are shown in Figure 3 . The first species had the parameters of $A_{0}=106 \times 10^{-4} \mathrm{~cm}^{-1}, g_{0}=1.98$ which corresponds to the $\mathrm{VO}^{2+}$ species $\left(A_{0}=106 \times 10^{-4} \mathrm{~cm}^{-1}\right.$, $\left.g_{0}=1.964\right) .{ }^{17}$ The second species observed had parameters of $A_{0}=97 \times 10^{-4} \mathrm{~cm}^{-1}, g_{0}=1.98$ and corresponds with the species previously reported. ${ }^{4-8}$ In the $10 \mathrm{mmol} \mathrm{L}^{-1} / 35 \mathrm{mmol} \mathrm{L}^{-1}$ sample two species are observed, one which corresponds to the complex observed in dilute sample. The minor species had the parameters of $A_{0}=102 \times 10^{-4} \mathrm{~cm}^{-1}, g_{0}=1.98$. On spiking the $7.0 \mathrm{mmol} \mathrm{L}^{-1} / 6.5 \mathrm{mmol} \mathrm{L}^{-1}$ sample with an equivalent amount of tartrate, the $\mathrm{VO}^{2+}$ species disappeared and the second complex species was formed. These two species with parameters of

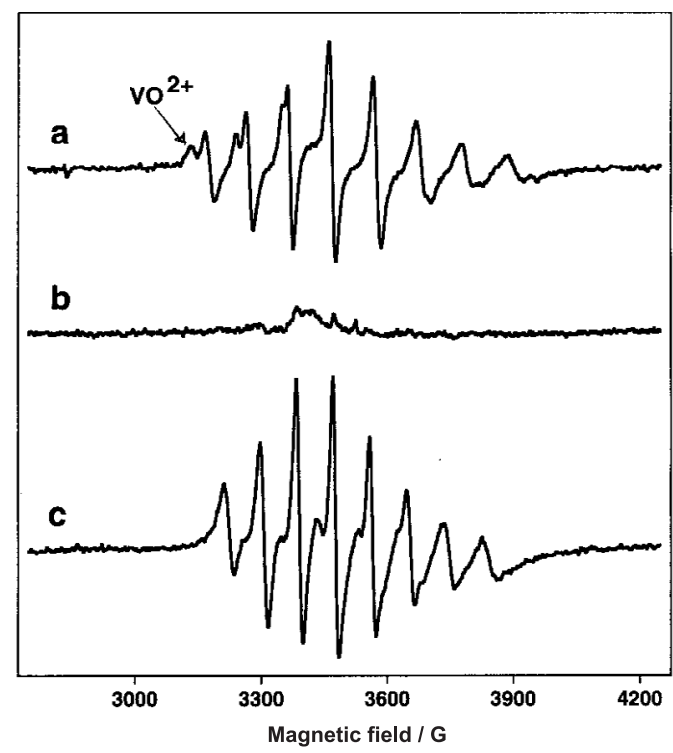

Figure 3. EPR spectra of (a) $7 \mathrm{mmol} \mathrm{L}^{-1}$ vanadate, $6.5 \mathrm{mmol} \mathrm{L}^{-1} \mathrm{~L}(+)$ tartaric acid and $600 \mathrm{mmol} \mathrm{L}^{-1} \mathrm{NaCl}$ at $\mathrm{pH} 2.50$ (fresh solution) and 10 mmol L ${ }^{-1}$ vanadate, $35 \mathrm{mmol} \mathrm{L}^{-1} \mathrm{~L}(+)$-tartaric acid and $600 \mathrm{mmol} \mathrm{L}^{-1} \mathrm{NaCl}$ at (b) fresh solution at pH 6.55 and at (c) after 4 days at $\mathrm{pH} 6.90$.

$A_{0}=97 \times 10^{-4} \mathrm{~cm}^{-1}, g_{0}=1.98$ and $A_{0}=102 \times 10^{-4} \mathrm{~cm}^{-1}$, $g_{0}=1.98$ correspond to the $1: 1$ species and $2: 2$ species previously reported. ${ }^{6-9}$

In contrast, no observable color change was observed within 24 to 30 hours in sample solutions with pH above 6.50. Accordingly, no EPR detectable V(IV) species was observed in freshly prepared sample solutions with 5 and 10-fold excess tartrate and 600 mmol L-1 $\mathrm{NaCl}$ at $\mathrm{pH} 6.55$. However, after 24 hours 8$10 \%$ and after 4 days $20 \%$ vanadium(IV) was observed with a major species at $A_{0}=81 \times 10^{-4} \mathrm{~cm}^{-1}, g_{0}=1.98$ and a minor species at $A_{0}=93 \times 10^{-4} \mathrm{~cm}^{-1}, g_{0}=1.98$ with a slight increase of $\mathrm{pH}$ to 6.90 .

\section{Complexes formed from enantiomerically pure and racemic tartaric acid}

The stereoisomers of the tartaric acid can be used to further explore the properties of the complexes further. Complexes containing one ligand stereoisomer, be it the $\mathrm{D}(-)$ - or $\mathrm{L}(+)$-tartaric acid isomer, will have identical stabilities. Complexes containing two ligand-stereoisomers may vary depending on whether the complex contains two D's (or two L's), or a DL(ד)-tartaric acid. The spectra of $10 \mathrm{mmol} \mathrm{L}^{-1}$ vanadate and $100 \mathrm{mmol} \mathrm{L}^{-1}$ L-tartaric acid with $600 \mathrm{mmol} \mathrm{L}^{-1} \mathrm{NaCl}$ were practically identical to spectra recorded of $10 \mathrm{mmol} \mathrm{L}^{-1}$ vanadate and $100 \mathrm{mmol} \mathrm{L}^{-1} \mathrm{D}(-)$-tartaric acid at $\mathrm{pH} 2.50$ with 600 mmol L-1 $\mathrm{NaCl}$ (Figure 4). However, mixing these solutions in a 1:1 ratio gives rather different spectrum in 
which the intensity of the $-539 \mathrm{ppm}$ signal was significantly greater than the $-515 \mathrm{ppm}$ signal (Figure 4). Identical spectra were obtained by mixing DL $(\bar{\mp})$-tartaric acid with vanadate. The differences in the concentration of $-539 \mathrm{ppm}$ species depending on the enantiomeric purity of the ligand suggest that the vanadium(V)-complex contains more than one ligand. These spectra show that the 1:2 complex at $-539 \mathrm{ppm}$ generated from the $\mathrm{DL}(\overline{+})-$ tartraric acid is more stable than the 1:2 complexes formed from enantiomerically pure tartraric acid.

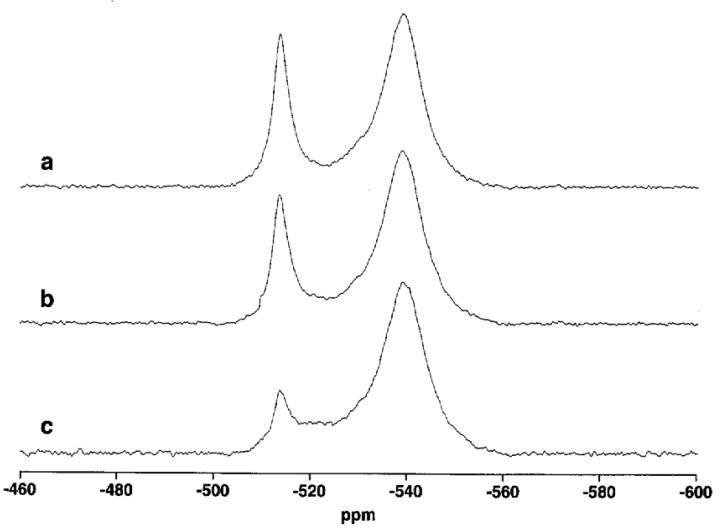

Figure 4. ${ }^{51} \mathrm{~V}$ NMR spectra of enantiomerically pure and racemic mixtures formed in solution of $10 \mathrm{mmol} \mathrm{L}^{-1}$ vanadate and $100 \mathrm{mmol} \mathrm{L}^{-1}$ tartaric acid complexes at $\mathrm{pH} 2.50$ in the presence of $600 \mathrm{mmol} \mathrm{L}^{-1} \mathrm{NaCl}$. The top spectrum show the complexes formed from $\mathrm{L}(+)$-tartaric acid, the middle spectrum show the complex formed from $\mathrm{D}(-)$-tartaric acid and the bottom spectrum show the complexes formed from DL $(\mp)$-tartaric acid.

Electrochemical investigations of the vanadium-tartrate system

Polarography. The polarograms were measured in solutions of vanadate $\left(1.0 \mathrm{mmol} \mathrm{L}^{-1}\right)$ and tartaric acid at a ratio $1: 1$ to $1: 10$ metal to ligand. The $\mathrm{V}(\mathrm{V})$ reduction show two irreversible waves in the $\mathrm{pH}$ range from 3.5 to 9.5 (Figure 5) (based on the analysis of $\log \left(I / I_{\lim }-I\right)$ dependence on $E$ ). Given the irreversibility of these waves polarography cannot be used to characterise the speciation. In this oxidation state, vanadium characteristically gives two cathodic waves as reported previously. ${ }^{18}$ Cathodic reduction of $\mathrm{V}(\mathrm{V})$ to $\mathrm{V}(\mathrm{IV})$ begins at $+0.3 \mathrm{~V}$ and no charging current region is observed as commonly found at dropping mercury electrode. The first wave is the one electron reduction of $\mathrm{V}(\mathrm{V})$ to $\mathrm{V}(\mathrm{IV})$ in agreement with previous report, ${ }^{18}$ while the second wave describes the reduction of $\mathrm{V}(\mathrm{IV}) .{ }^{18}$ The second reduction wave appears at a negative potential $(-1.0 \mathrm{~V}$ to $-1.2 \mathrm{~V})$. Since the limiting current of that wave is approximately two-fold higher than that of the $\mathrm{V}(\mathrm{V})$ reduction to $\mathrm{V}(\mathrm{IV})$, the participation of two electrons in the reduction process is inferred. Therefore this wave is the $\mathrm{V}(\mathrm{IV})$ reduction to $\mathrm{V}(\mathrm{II})$.

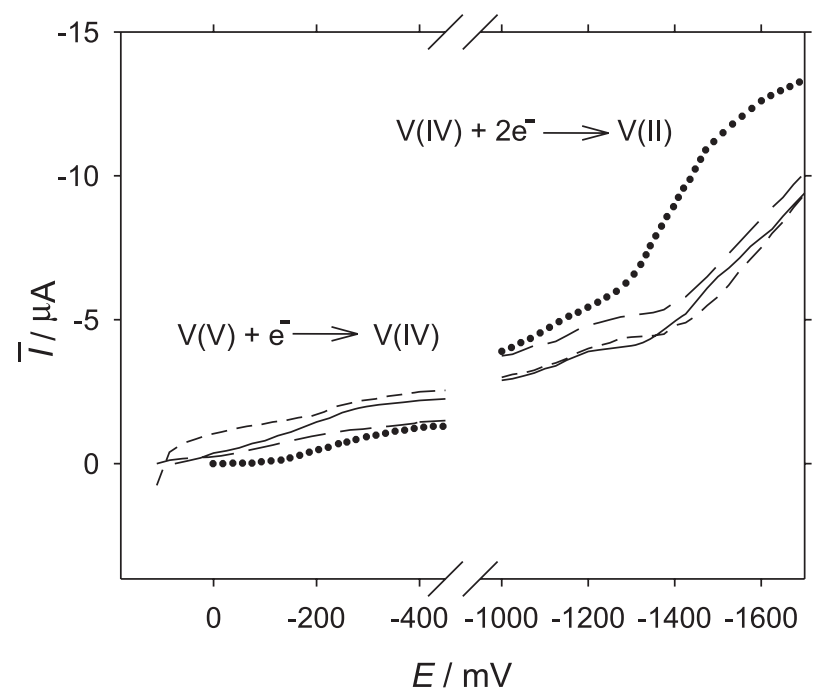

Figure 5. Polarograms of the $\mathrm{V}(\mathrm{V})$ cathodic reduction. Solution composition: $1 \mathrm{mmol} \mathrm{L}^{-1} \mathrm{~V}(\mathrm{~V}), 600 \mathrm{mmol} \mathrm{L}^{-1} \mathrm{NaCl}, \mathrm{L}(+)$-tartaric acid: $\cdots \cdots \cdots(0$

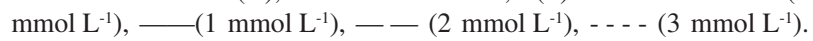
$\mathrm{pH}=5.5$.

At pH 2.5 (Figure 6), three cathodic waves were obtained and correspond to stepwise reduction to V(IV) (at ca. $+0.3 \mathrm{~V}$ ), $\mathrm{V}$ (III) (at $c a .-0.95--1.0 \mathrm{~V}$ ) and $\mathrm{V}$ (II) (at ca. $-1.2 \mathrm{~V}$ ), respectively. The decrease in limiting current of the second and the third wave with the increase in tartaric acid concentration confirms the participation of tartaric acid in complex formation.

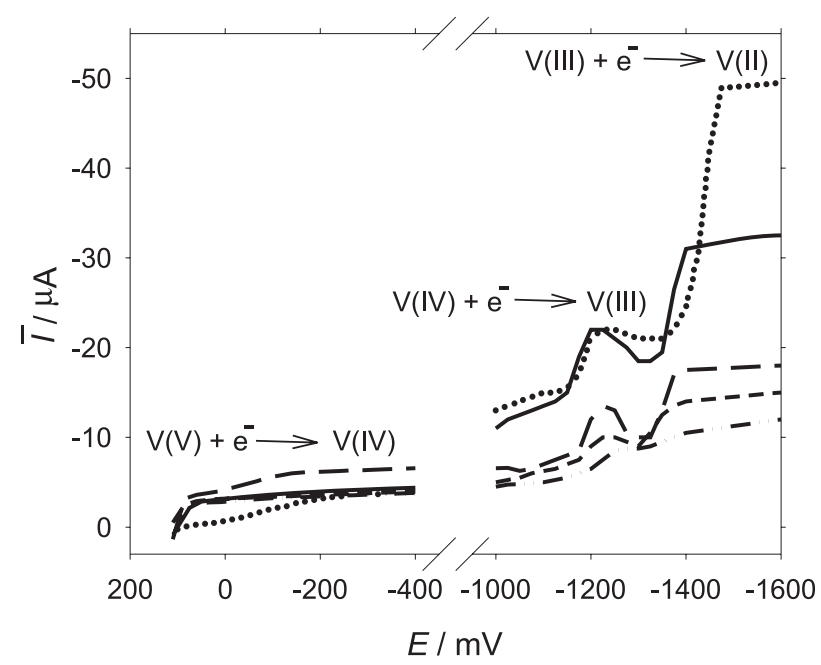

Figure 6. Polarograms of the $\mathrm{V}(\mathrm{V})$ cathodic reduction. Solution composition: $1 \mathrm{mmol} \mathrm{L}^{-1} \mathrm{~V}(\mathrm{~V}), 600 \mathrm{mmol} \mathrm{L}^{-1} \mathrm{NaCl}, \mathrm{L}(+)$-tartaric acid: ......... $\left(0 \mathrm{mmol} \mathrm{L}^{-1}\right),-\left(1 \mathrm{mmol} \mathrm{L}^{-1}\right),-$ - $\left(2 \mathrm{mmol} \mathrm{L}^{-1}\right),-$ - - $\left(3 \mathrm{mmol} \mathrm{L}^{-1}\right)$, $-\cdot \cdot-\cdot \cdot-\left(10 \mathrm{mmol} \mathrm{L}^{-1}\right) \cdot \mathrm{pH}=2.5$.

In the polarograms of solutions at $\mathrm{pH} 3.5-9.5$, the height of the waves of $\mathrm{V}(\mathrm{IV})$ reduction to $\mathrm{V}$ (II) decreases by approximately a factor of two in the presence of L-tartrate which is interpreted as the formation of a larger species with lower diffusion coefficient (Figure 5). Since 
the polarographic waves of V(IV) reduction are diffusion limited (the temperature coefficient of the limiting current is $c a .1 .5-1.8 \% \mathrm{deg}^{-1}$ ) the diffusion coefficient values could be calculated as described in the experimental section. Some change in the diffusion coefficients with varying of $\mathrm{pH}$ is anticipated and was observed. Solutions containing the simple vanadate salt gave diffusion coefficients at $10 \times 10^{-6}$ and $15 \times 10^{-6} \mathrm{~cm}^{2} \mathrm{~s}^{-1}$ at $\mathrm{pH} 3.5$ and 5.5 to $25 \times$ $10^{-6} \mathrm{~cm}^{2} \mathrm{~s}^{-1}$ at $\mathrm{pH} 7.5$ to 9.5 . It is possible that a further detailed study can provide additional information of ionic species in these solutions of V(IV) and various oligomeric and polymeric forms in the physiological $\mathrm{pH}$ range. Moreover, in the presence of excess ligand, the same pattern was observed. At $\mathrm{pH} 3.5$ and 5.5, the diffusion coefficients were $3 \times 10^{-6}$ and $6 \times 10^{-6} \mathrm{~cm}^{2} \mathrm{~s}^{-1}$. At $\mathrm{pH} 7.5$ and 9.5 , the diffusion coefficients were $12 \times 10^{-6}$ and $17 \times 10^{-6} \mathrm{~cm}^{2} \mathrm{~s}^{-1}$ respectively. Given the fact that the pure salt resulted in a much lower current, the observed diffusion coefficient of the salt will be much larger. However, free ligand yields higher currents. Accordingly, if solutions of vanadium-tartaric acid complexes contained some free ligand this should result in underestimation of a diffusion coefficient for the complexes. Since complexes are in equilibrium with free ligand and vanadate as demonstrated by NMR spectroscopy it became important to determine whether there was free ligand under such electrochemical investigations. As shown below using cyclic voltammetry free ligand was observed in these solutions, and the diffusion coefficients above have minimum values. Furthermore, these measurements represents an average value of the vanadium(IV) complexes that exist in solution.

Cyclic voltammetry. The cyclic voltammograms were recorded in solutions of vanadate, $\mathrm{L}(+)$ - and DL( $(\overline{+})$ tartrate and complexes at a potential scan rate $50 \mathrm{mV} \mathrm{s}^{-1}$ (Table 1). A representative scan is shown in Figure 7 at $\mathrm{pH}$ 2.5. The ratios of vanadate to tartaric acid vary from $1: 1$ to $1: 3$. The cyclic voltammogram of vanadate and tartaric acid alone is different than that observed from the complex as shown in Figure 7. For the complex, a well-defined V(V)-V(IV)-L(+)-tartaric acid redox couple was observed at peak potentials of $+0.93 \mathrm{~V}$ and $+0.37 \mathrm{~V}$, which is a region where no electrochemical process was observed for either vanadate or tartrate ligand. As it is seen from voltammograms this process is irreversible. Thus, this fact suggests that the electron transfer process is accompanied by additional chemical reaction, as can be anticipated vanadium(V) forms 1:1 and $1: 2$ complexes with tartaric acid, and vanadium(IV) forms $2: 2$ complexes. In the potential region approxi-

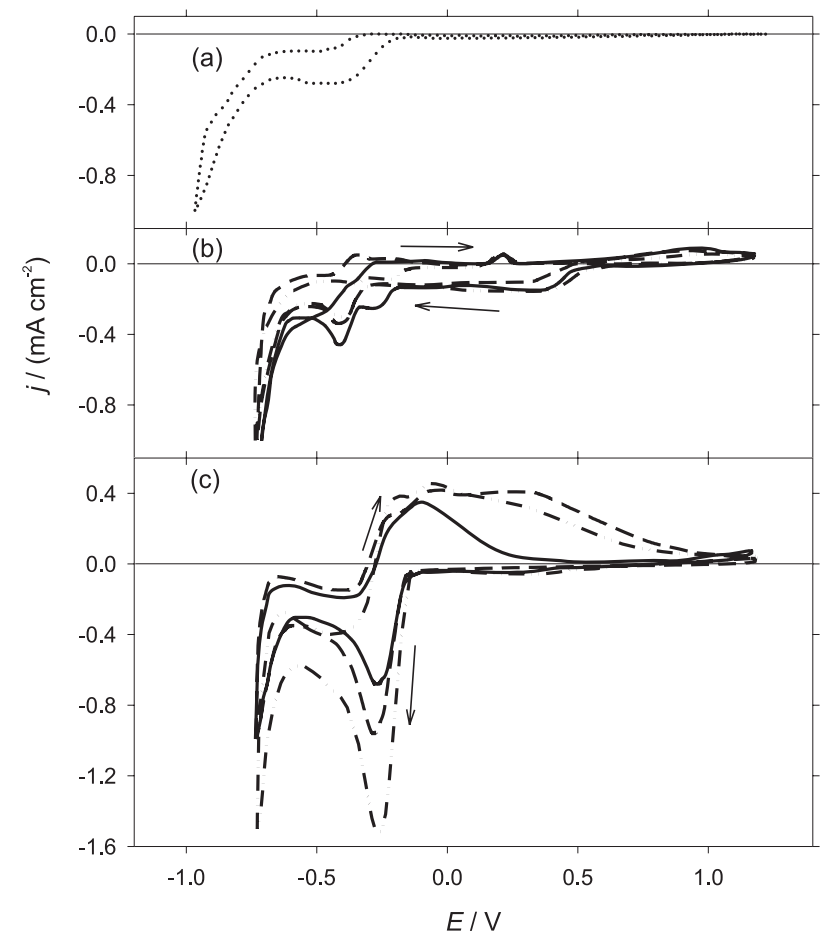

Figure 7. Cyclic voltammograms observed in reductive scan: V(V) (a), $\mathrm{V}(\mathrm{V})$ in the presence of $\mathrm{L}(+)$-tartaric acid (b), and $\mathrm{L}(+)$-tartaric acid (c). $10 \mathrm{mmol} \mathrm{L}^{-1} \mathrm{~V}(\mathrm{~V}), 600 \mathrm{mmol} \mathrm{L}{ }^{-1} \mathrm{NaCl}, \mathrm{L}(+)$-tartaric acid: - $(10$ $\mathrm{mmol} \mathrm{L}-1),-\cdots\left(20 \mathrm{mmol} \mathrm{L}^{-1}\right),-\cdot-\cdot \cdot-\left(30 \mathrm{mmol} \mathrm{L}^{-1}\right) ; \mathrm{pH}=2.5$.

mately from $-0.1 \mathrm{~V}$ to $-0.7 \mathrm{~V}$ the decrease in reduction current from the ligand compared to the complex is consistent with the complexation of tartaric acid with the $\mathrm{V}(\mathrm{V})$. Two peaks are observed in the complex cyclic voltammogram in this region, one of which is new and can be attributed to a reduction of $\mathrm{V}(\mathrm{V})$ to a lower oxidation state. This process is also irreversible. The other peak is at the same potential as a peak in the tartaric acid curve which is likely due to the small presence of uncomplexed tartaric acid.

A series of different $\mathrm{pH}$ values were investigated and different cyclic voltammograms were observed. The series of cyclic voltammograms of vanadate, tartrate and complex at $\mathrm{pH} 6.5$ are shown in Figure 9. At $\mathrm{pH}$ 6.5, the $\mathrm{V}(\mathrm{V})-\mathrm{V}(\mathrm{IV})-\mathrm{L}(+)$-tartrate was found to give a peak separation of $60 \mathrm{mV}$ and a ratio of $I_{\mathrm{pc}} / I_{\mathrm{pa}} \sim 1$ (Figure 8), which corresponds to a reversible redox process. Increasing the $\mathrm{pH}$ to 9.5 completely eliminated the peaks

Table 1. Voltammetric characteristic of V(V) reduction in the presence of tartrate

\begin{tabular}{lcccc}
\hline $\mathrm{pH}$ & \multicolumn{2}{c}{$\mathrm{L}(+)$-tartaric acid } & \multicolumn{2}{c}{$\mathrm{DL}(\mp)$-tartaric acid } \\
& $E_{1 / 2} /(\mathrm{V})$ & $\Delta E_{\mathrm{p}} /(\mathrm{V})$ & $E_{1 / 2} /(\mathrm{V})$ & $\Delta E_{\mathrm{p}} /(\mathrm{V})$ \\
\hline 2.5 & 0.65 & 0.56 & 0.68 & 0.48 \\
3.5 & 0.68 & 0.47 & 0.62 & 0.44 \\
5.5 & 0.01 & 0.22 & - & - \\
6.5 & 0.41 & 0.06 & 0.03 & 0.26 \\
\hline
\end{tabular}


at this potential (data not shown) suggesting that both the vanadium(IV) and (V) complexes which undergoes reversible redox chemistry no longer exist or dramatically changed structure at $\mathrm{pH} 9.5$.

Interestingly, the cyclic voltammograms of vanadium(V) solutions containing DL $(\overline{+})$-tartrate as ligand are significantly different from that of $\mathrm{L}(+)$-tartrate. Although the cyclic voltammograms of tartrate have several identifiable features, the differences were observed in the shapes of the

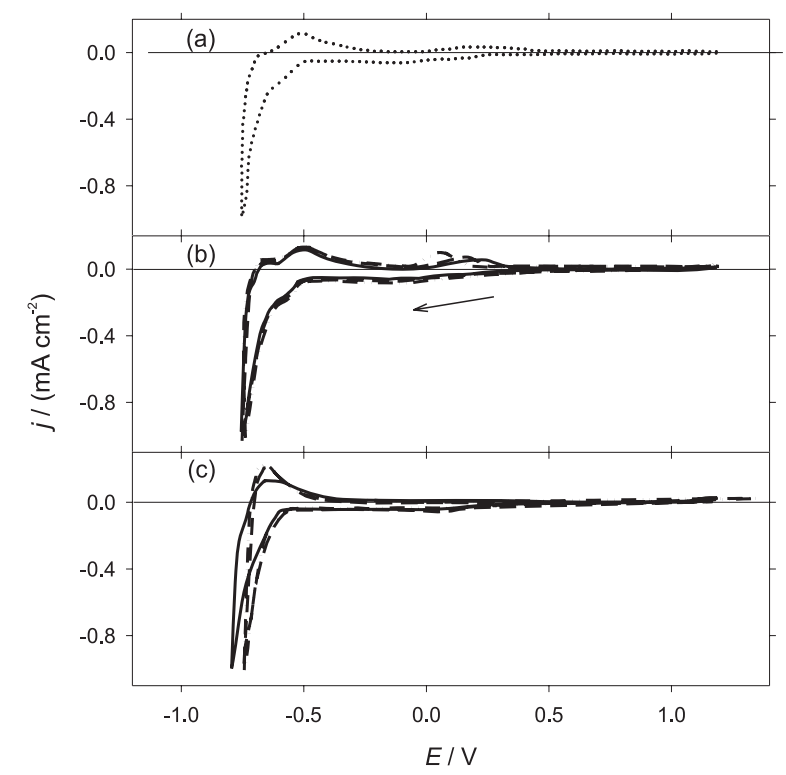

Figure 8. Cyclic voltammograms observed in reductive scan: $\mathrm{V}(\mathrm{V})(\mathrm{a})$, $\mathrm{V}(\mathrm{V})$ in the presence of $\mathrm{L}(+)$-tartaric acid (b) , and $\mathrm{L}(+)$-tartaric acid (c). $10 \mathrm{mmol} \mathrm{L}-1 \mathrm{~V}(\mathrm{~V}), 600 \mathrm{mmol} \mathrm{L}^{-1} \mathrm{NaCl}, \mathrm{L}$-tartaric acid: —— $\left(10 \mathrm{mmol} \mathrm{L}^{-1}\right)$, - . - $\left(20 \mathrm{mmol} \mathrm{L}^{-1}\right),-\cdot \cdot-\cdot-\left(30 \mathrm{mmol} \mathrm{L}^{-1}\right) ; \mathrm{pH}=6.5$.

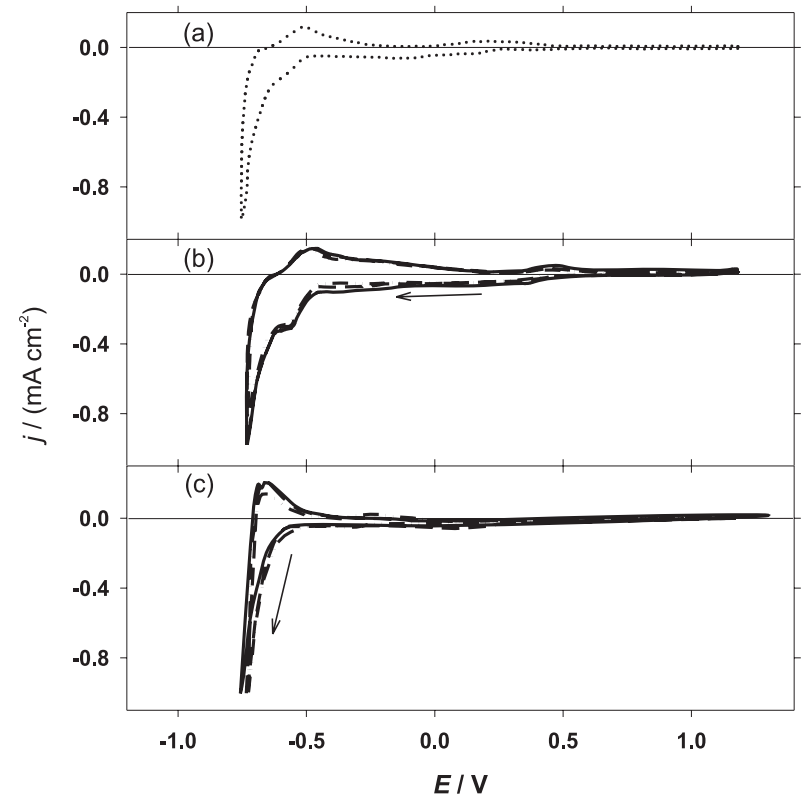

Figure 9. Cyclic voltammograms observed in reductive scan: $V(V)$ (a), $\mathrm{V}(\mathrm{V})$ in the presence of DL( $($ )- tartaric acid (b), and DL $(\mp)$ - tartaric acid (c). $10 \mathrm{mmol} \mathrm{L}^{-1} \mathrm{~V}(\mathrm{~V}), 600 \mathrm{mmol} \mathrm{L}^{-1} \mathrm{NaCl}, \mathrm{DL}(\mp)$ - tartaric acid: $\left(10 \mathrm{mmol} \mathrm{L}^{-1}\right),-\cdots\left(20 \mathrm{mmol} \mathrm{L}^{-1}\right),-\cdot \cdot-\cdot \cdot\left(30 \mathrm{mmol} \mathrm{L}^{-1}\right) ; \mathrm{pH}=6.5$. voltammograms and the position of the reduction and oxidation current peaks (Table 1) (Figure 8 and Figure 9). Possible sources of these changes include differential stability, ligand oxidation and differential adsorption at the electrode surface. Variability between the complexes stability seems less likely when considering that the stability constants of $1: 1$ complexes of other transition metal ions $(\mathrm{Cu}(\mathrm{II}), \mathrm{Sb}(\mathrm{III})$, $\mathrm{Fe}(\mathrm{II}))$ with $\mathrm{L}(+)$ - and DL( $(\overline{+})$-tartaric acid are similar. ${ }^{19,20}$ However, differential stabilities were observed for the vanadium(V) $\mathrm{L}(+)$ - and $\mathrm{DL}(\bar{\mp})$-tartaric acid 1:2 complex. Differential stabilities are particularly feasible when respective complexes contain more than one ligand (which found in the $\mathrm{V}(\mathrm{V}) / \mathrm{V}(\mathrm{IV})$-tartrate system). Alternatively, the different electrochemical behavior of $\mathrm{V}(\mathrm{V}) / \mathrm{V}(\mathrm{IV})$ complexes with $\mathrm{L}(+)$-tartaric and DL( $(\bar{\mp})$-tartaric acids could be due to differential adsorption of the complexes on the electrode surface. Without further investigations it is hardly likely to distinguish these possibilities. Precedent for this effect has been reported for $\mathrm{Cu}(\mathrm{II})$ complexes with $\mathrm{L}(+)$ - and $\mathrm{DL}(\overline{+})-$ tartaric acid when the process of electroless copper plating was investigated using formaldehyde as a reducing agent. ${ }^{21,22}$ The rate of copper deposition and real surface area of the coatings are about 3 times higher in DL( $(\bar{F})$-tartaric acid solutions compared with these parameters in $\mathrm{L}(+)$-tartaric acid solutions. ${ }^{21}$ These differences are in contrast to the similar complexation by $\mathrm{L}(+)$ - and $\mathrm{DL}(\overline{+})$-tartrate of $\mathrm{Cu}(\mathrm{II})$ ions in alkaline solutions. ${ }^{22}$

\section{Conclusions}

Characterization of vanadium(V) complexes with tartaric acid was undertaken using multinuclear NMR spectroscopy and supported by EPR spectroscopy. Two major species were observed, one with a stoichiometry of $1: 2$ and a second complex with a stoichiometry of $1: 1$. The 1:2 complex formed from enantiomerically pure Ltartrate ligand was less stable than that of the 1:2 complex formed from racemic DL( $\overline{+})$-tartrate ligand. The stability of the 1:2 complex of the $\mathrm{L}(+)$ - or $\mathrm{D}(-)$-tartrate ligand was found to be lower than that of the 1:2 complex with the DL(F)-tartrate ligand.

The redox chemistry of these complexes was characterized using the electrochemical methods, particularly polarography and cyclic voltammetry. Diffusion coefficients were calculated from the polarographic data and the minimum average values for the diffusion coefficient for the vanadium(IV)-tartrate 2:2 complexes were determined to range from $3 \times 10^{-6} \mathrm{~cm}^{2} \mathrm{~s}^{-1}$ to $17 \times 10^{-6} \mathrm{~cm}^{2} \mathrm{~s}^{-1}$ depending on $\mathrm{pH}$. Cyclic voltammetry confirmed results obtained using NMR and EPR that complex formation depends on $\mathrm{pH}$ and tartrate enantiomer. 


\section{Acknowledgments}

EN thanks the Lithuanian State Science and Studies Foundation for financial support (Project T-17/06). DCC thank the National Institutes of Health, General Medical Sciences for partial funding. In addition, DDC and EN thank the American Chemical Society and COBASE for funding the visitor exchange program.

\section{References}

1. Thompson, K. H.; McNeil, J. H.; Orvig, C.; Chem. Rev. 1999, 99, 2561; Sakurai, H.; Sano, H.; Takino, T.; Yasui, H.; Chem. Lett. 1999, 913; Crans, D. C.; Smee, J. J.; Gaidamauskas, E.; Yang, L. Q.; Chem. Rev. 2004, 104, 849; Yang, X. G.; Yang, X. D.; Yuan, L.; Wang, K.; Crans, D. C.; Pharm. Res. 2004, 21, 1026; Sakurai, H.; Funakoshi, S.; Adachi, Y.; Pure Appl. Chem. 2005, 77, 1629; Crans, D. C.; Pure Appl. Chem. 2005, 77, 1497; Buglyó, P.; Crans, D. C.; Nagy, E. M.; Lindo, R. L.; Yang, L.; Smee, J. J.; Chi, L.-H.; Godzala III, M. E.; Willsky, G. R. Inor. Chem. 2005, 44, 5416.

2. Clague, M. J.; Butler, A.; J. Am. Chem. Soc. 1995, 117, 3475; Rehder, D. In Bioinorganic Chemistry. Transition Metals in Biology and Their Coordination Chemistry; Trautwein, A. X., ed.; Wiley-VCH: New York, 1997; Rehder, D.; Jantzen, S.; Vanadium in the Environment. Part 1: Chemistry and Biochemistry, John Wiley \& Sons: New York, 1998.

3. Eady, R. R. In Metal Ions in Biological Systems; Sigel, H.; Sigel, A., eds.; Marcel Dekker: New York, 1995, vol. 31.

4. Druekhammer, D. G.; Durrwachter, J. R.; Pederson, R. L.; Crans, D. C.; Daniels, L.; Wong C.-H.; J. Org. Chem. 1989, 54, 70; Nour-Eldeen, A. F.; Craig, M. M.; Gresser, M. J.; J. Biol. Chem. 1985, 260, 6836.

5. Ghosh, B. N.; Moulik, S. P.; Sengupta, K. K.; Pal, P. K.; J. Indian Chem. Soc. 1963, 40, 509.

6. Tapscott, R. E.; Belford, R. L.; Inorg. Chem. 1967, 6, 735.
7. Tapscott, R. E.; Belford, R. L.; Paul, I. C.; Inorg. Chem. 1968, 7, 356 .

8. Tapscott, R. E.; Belford, R. L.; Paul, I. C.; Coord. Chem. Rev. 1969, 4, 323.

9. Kiss, T.; Buglyo, P.; Sanna, D.; Micera, G.; Decock, P.; Dewaele, D.; Inorg. Chim. Acta 1995, 239, 145.

10. Norkus, E.; Vaškelis, A.; Polyhedron 1994, 13, 3041.

11. Bard, A. J.; Faulkner, L. R.; Electrochemical Methods. Fundamentals and Applications, John Wiley \& Sons: New York, 1980.

12. Norkus, E.; Pauliukaite, R.; Vaškelis, A.; Polish J. Chem. 1999, 73, 1837.

13. Crans, D. C.; Shin, P. K.; J. Am. Chem. Soc. 1994, 116, 1305.

14. Amin, S. S.; Cryer, K.; Zhang, B.; Dutta, S. K.; Eaton, S. S.; Anderson, O. P.; Miller, S. M.; Reul, B. A.; Brichard, S. M.; Crans, D. C.; Inorg. Chem. 2000, 39, 406.

15. Heyrovsky, J.; Kuta, J.; Principles of Polarography, Academic Press: New York, 1966.

16. Pettersson, L.; Andersson, I.; Howarth, O. W.; Inorg. Chem. 1992, 31, 4032.

17. Chasteen, N. D. In Biological Magnetic Resonance; Berliner, L.; Reuben, J., eds.; Plenum Press: New York, 1981, vol. 3.

18. Bard, A. J., ed.; Encyclopedia of Electrochemistry of the Elements; Marcel Dekker: New York, 1978, vol. 7.

19. Sillen, L. G.; Martell, A. E., eds.; Stability Constants of MetalIon Complexes. Special Publication No 17, Supplement No 1; Chemical Society: London, 1964.

20. Sillen, L. G.; Martell, A. E., eds.; Stability Constants of MetalIon Complexes. Special Publication No 17, Supplement No 1; Chemical Society: London, 1971.

21. Norkus, E.; Vaškelis, A.; Stalnioniene, I.; J. Solid State Electrochem. 2000, 4, 337.

22. Norkus, E.; Vaškelis, A.; Zakaite, I.; Chemija (Vilnius) 1997, 2,16 .

Received: January 17, 2006

Published on the web: June 20, 2006 